\title{
Study on Florens' Inferiority Feeling in "A Mercy"
}

\author{
Yang Yang \\ Foreign Language School \\ Huanghe Science and Technology College \\ Zhengzhou, China
}

\begin{abstract}
As the first African-American woman who won the Nobel Prize for literature, Toni Morrison has always been yelling and fighting on the miserable position of the black people, especially the black women. Apart from the racial discrimination as her previous novels, her latest novel A Mercy (2008) transcends the race and sex, and puts concern on all the people under the slavery system. Under the oppression of slavery, people suffer not only physical affliction but also spiritual torture. Being discriminated by the society, people under slavery are entrapped into the inferiority feelings. They try to escape the inferiority feelings by all means. However, according to Alfred Adler, without social interest, the efforts they have made gain no improvement. On the contrary, their inferiority feelings grow more serious. Only with the social interest and the devotion to making contribution to others and the society, can people transcend the inferiority feelings with their self-value fulfilled. This thesis tries to analyze the inferiority feelings of the characters in A Mercy according to Alfred Adler's inferiority theory to prove that the selfaccomplishment builds on the love that people give instead of the love they ask for.
\end{abstract}

Keywords-Toni Morrison; A Mercy; inferiority feelings; compensation; transcendence

\section{INTRODUCTION}

As the first black woman to receive Nobel Prize in literature, Toni Morrison is one of the most celebrated writers of the contemporary American literature. During her more than forty years' writing career ever since her first novel The Bluest Eye was published in 1970, her books have won the National Book Critics Circle Award, the Pulitzer Prize for fiction, the American Book Award, the Nobel Prize in Literature and so on. She was also honored with the 1996 National Book Foundation's Medal of Distinguished Contribution to American Letters.

\section{A. Toni Morrison and her A Mercy}

Toni Morrison, born Chloe Anthony Wofford on February 18, 1931 in Lorain, Ohio, is the second of the four children in the black working-class family. Morrison's father, George Wofford, has influenced her later life deeply by encouraging her to develop her creativity and great interest in literature. After Toni Morrison received a Bachelor of Art in English from Howard University in 1953, she earned a Master of Arts degree in English from Cornell University in 1955. After graduation, she began her teaching career and taught young writers in Texas Southern University and
Howard University. After Morrison's divorce from her first husband Harold Morrison, she moved to Syracuse, New York, to work as an editor. Not long after she moved to Syracuse, she began to work as an editor at the Random House and played a vital role in bringing black literature into the mainstream, editing books by the young black novelists.

As a great novelist, Toni Morrison has made great accomplishments in American literature circle. Her novel Beloved(1987) won both of the Pulitzer Prize for fiction and the American Book Award. It also was called the best American novel published in the previous twenty-five years. She was awarded the Nobel Prize in literature in 1993 and her citation reads: Toni Morrison, "who, in novels characterized by visionary force and poetic import, gives life to an essential aspect of American reality." She is selected for the Jefferson Lecture by the National Endowment for the Humanities in 1996. In the same year, Morrison was honored with the 1996 National Book Foundation's Medal of Distinguished Contribution to American Letters, which is awarded to a writer who has enriched American literary heritage over a life of service, or a corpus of work.

A Mercy joins Toni Morrison's celebrated body of work exploring the African American experiences of slavery and freedom. Once published, it is regarded as one of the "best books of 2008" by the New York Times critics. Henry L. Carrigan says in his review "A Mercy" published in Literary Journal 133.17 that this novel deserves to be treasured by every library. The magazine Economist 389.8605 says in the article "Mercy Mission" that this novel is equated to Morrison's master work Beloved. Jennifer McKeown's review "Mothers and Daughters" talks about what women were suffering in the slavery, and said that "all women in this world are at the mercy of the men in their lives; without them, these women are as good as lost". In her view, to be a female in slavery is to be an open wound that cannot heal; even if scars form, the festering is ever below. The New York Times has published several book reviews about A Mercy. David Gates published the article entitled "Original Sins" on November 28, 2008 to describe the crimes the Europeans did to the natives and slaves. Another article published in The New York Times is Michiko Kakutani's "Bonds that Seem Cruel can be Kind". It regards A Mercy as a variation on Beloved's exploration of the personal costs of slavery-a system that moves men and women and children around like checkers and casts a looming shadow over both parental and romantic love. In the article it says that "all the central characters in this story are orphans, cast off by their parents 
or swept away from their families by acts of God or nature or human cruelty".

According to the National Public Radio's website, Toni Morrison tries to find just the right word to cover the book's denouement and she fiddles around with the word "mercy", but that didn't feel quite right, for the book isn't about largescale compassion or pity or grace. With the help of her editor, she put an article in front: A Mercy. With the small word, the title suggests that just out of a human gesture-mercy-that makes Florens a place to keep safe.

Like her previous novels, A Mercy is about the slavery. However, in this novel, Toni Morrison tries to remove race from slavery. In A Mercy, not only the black but also the white are slaves. The novel is set in American of 17th century when the race and color was not so important and people of different colors live both in physical and spiritual enslavement. The novel happens in the farm of Jacob Vaark where Native American, black child, orphan and indentured servants are united in a spreading culture of servitude that has little to do with skin color. The story is told in the young slave girl Florens' tone with flashbacks and time-shifts. In the little girl's mind, she was abandoned by her mother. When her mother faced the choice of keeping Florens or her little brother, she chose to send Florens away. Florens was sold to Jacob Vaark who is a different landholder from the ones who trade and abuse the slaves. Florens' mother begs Jacob to take her daughter away because the girl is in danger of falling into worse hands and he seems human.

\section{B. Inferiority Feelings}

Inferiority feeling is Alfred Adler's (1870-1937) most famous concept which relates to the problem of self-esteem and its negative effects on human health. Alfred Adler is an Austrian medical doctor, psychologist and founder of the school of individual psychology. The concept of inferiority feelings and compensation originates from Adler's early studies of organ inferiority and compensation. In Adler's Study of Organ Inferiority and its Physical Compensation (1907), he asserts that all neurosis derives from congenital weakness-organ inferiority-such as visual or hearing impairment and those who have organ inferiority will strive to overcome their congenital debility in a struggle for social adaptation which is called Compensation by Adler later. Some will overcome their disabilities or limitations in compensation, such as Demosthenes, who becomes a great speaker in compensation for an early defect in speech. However, some with similar problems do not compensate by excelling but takes his or her defect as an excuse to preserve their fantasy that they would have gained prestige if they had not had the defect. As Adler's paper is published in 1907, Sigmund Freud takes the point that Adler holds as a great contribution to his ego psychology and regards the compensation as a kind of function of the ego. At that time, Freud invites Adler to join his Vienna Psychoanalytic Society. As Adler's thoughts develop into an independent system, he declares that the compensation is the central points of his theory. The key conflict between Freud and Adler lies in that Freud holds his sexual Libido theory as the determinant force in people's life while Adler insists that what determines people's life is how they express the innate striving for mastery, competence and power.

Shortly after Adler's study of organ inferiority, he develops it into the inferiority feeling in everyone. The child maybe finds that he is inferior in doing almost everything comparing with the adults, no matter physically or mentally. Because he is weak and small, he needs to depend on the adults and every activity of his would be controlled by the adults. As he is growing up, he may excel himself to get rid of his dependence on the adults and the adults' control on him. He is making his effort to be strong and able to compensate his inferiority feeling before. Then the feeling of inferiority is transcended. However, some may take this inferiority feeling as the excuse to avoid doing what he is able to do. And when he is discouraged or unwilling to get rid of his feelings of inferiority, he will try to be superior to difficulties by hypnotizing himself or auto-intoxicating himself into feeling superior instead of overcoming obstacles. And that leads to the development of inferiority feelings.

\section{THE ORIGIN OF FLORENS' INFERIORITY FEELINGS}

According to Adler's theory about family and environment, "the growing infant takes into account all the impressions he receives, those from his own body and those from the external environment, and under their influence creatively forms his opinion of himself and the world, together with his idea of his individual goal of success" (Ansbacher, 1956: 366). He believes that the early recollections of the child are of especial importance to his later life because they can show the origins of an individual's life style. People from a sphere of insecurity in childhood usually grow under the pressure of inferiority and their willing and thinking are built upon the foundation of a feeling of inferiority. In that case, family and living environment play a crucial role in the life of people with inferiority feelings.

As the child is born with smallness and helplessness in the world, he is exposed to the environment of adults and "tempted to regard himself as small and weak to appraise himself as inadequate and inferior" (Ansbacher, 1956: 116). Feeling inferior and insecure in the strange world, the first intimate relationship a child can hold is that with his parents. Parental care and love is the first safeguarding he can feel and trust. Once he lost his contact with parental love, he would feel the abandonment by his trusted ones. If there is no way for them to pour out that disappointment and shame, the inferiority feeling will be accumulated.

Florens spends her childhood with her mother and little brother without knowing whom her father is. As a slave, her mother has no ability to protect her adolescent daughter. She can see the eyes following her young daughter but she has no way to avoid the danger because she knows that "To be female in this place is to be an open wound that cannot heal" (Morrison, 2008: 163).When she cannot offer protection for her little girl, she turned to God. She hopes her daughter can learn letters from Reverend Father so that someday she can make her way. Actually she does not believe that God could help her, she just trusts the magic of learning. However, the 
power of learning is not strong enough to protect her. As soon as Florens' mother sees Jacob, she recognizes the difference of Jacob from her owner. She knows that there will be no protection but there will be difference. She knows that her owner will not allow herself to be purchased, but he will permit her children to be purchased. She chooses to offer her daughter to the stranger farmer, Jacob. However, as an eight-year-old little girl, Florens takes her mother's action as abandonment. Having witnessed the abandonment by her mother, she lives in the insecurity all day long. She dreamed more than once the scene that her mother asked Jacob to take her away. "Her baby boy is still at her breast. Take the girl, she says, my daughter, she says. Me. Me" (Morrison, 2008: 7). The repetition of this scene makes her resolution for love much firmer. Many times she dreams that her mother tries to tell her something, but in her mind there is only one thing she cares - her mother chooses the little boy other than her. "I look away from her" (Morrison, 2008: 101). As she arrives at Jacob's farm, Lina regards Florens as her own and believes "she would be the opposite of incorrigible Sorrow....Not only was she consistently trustworthy, she was deeply grateful for every shred of affection, any pat on the head, any smile of approval" (Morrison, 2008: 61). The indentured servant Scully also finds that she is "a combination of defenselessness, eagerness to please and, most of all, a willingness to blame herself for the meanness of others" (Morrison, 2008: 152). There is no other way except putting herself in a low enough position to get the approval of others. As a little girl who believes that her mother has abandoned her, Florens lives her life always in the danger of being abandoned.

The impression of her mother's abandonment is so deep that her life is always in the shadow of inferiority manifested by her fear for being rejected, hated and chagrined.

\section{COMPENSATION OF THE INFERIORITY FEELINGS}

In Alfred Adler's Study of Organ Inferiority (1907), it states that if there is an organ inferiority that will threaten to destroy the organic balance in the organ-environment interaction, the balance responds to the damage through attempts at compensation. As the mind is the superstructure of the central nervous system in people's entire organism, it plays the central role in the process of compensation of equilibrium. Then it comes to the concept of psychological compensation. In Adler's theory, the dominating force in the completely open system of dynamic system of the organism is a ceaseless upward striving. This striving is the drive from inferiority to superiority, from below to above, while the meaning of superiority or above means the striving for enhancement of one's self-esteem or for the safeguarding of it. Adler assumes that everyone has a feeling of inferiority and that is the cause of all improvements in the position of mankind due to the striving for superiority. Since no one can bear the inferiority feeling for long, he will still be unable to bear his feeling of inferiority even he is discouraged to be superior, and he will still struggle to get rid of it. What people do to compensate their inferiority feelings is to keep the safeguarding and defense for oneself with their behaviors. People have the goal to be superior and "consequently the striving is toward superiority and finally that the striving is compensatory, originating in a feeling of inferiority" (Ansbacher, 1956: 101). In the effort of striving for superiority, people with inferiority feelings will not insist on improving the environment or themselves, but will try to hypnotize himself into feeling superior in spite of the fact that the goal is merely to gain the superiority feeling no matter to what he is superior.

Living in the shadow of inferiority feelings, people make great efforts to highlight themselves to make compensation. According to Adler, to get rid of the inferiority feelings, the one will try his best to pursue a satisfaction to cover up his inferiority. The satisfaction aims at improving his unfavorable situation and make compensation to his inferiority feelings. As one feels inferior for being abandoned by parents and unwelcomed by the society, he will try his best to get approval of others to satisfy his desire to be superior to the previous self. The drive for superiority will direct to his self and the life goal will be not the social interest, but the interest on his own person only. As Heinz L. Ansbacher says in The Individual Psychology of Alfred Adler, "an important variation of the drive directed to one's own person is looking and listening within, together with recollection, intuition, introspection, premonition, illusion, hallucination, and anxiety" (Ansbacher, 1956: 33).

In A Mercy, both Florens and Sorrow lose love and warmth since childhood; they are too weak to make any change of their situation. Due to the lack of love, they cannot obtain the deserved sense of security and feeling of home from family. In that case, to compensate the lack of family love and warmth, they desire to get the approval and appreciation from others to. Florens is grateful for even a nod or a smile of approval. As for Sorrow, feeling lonely in the world, she closes her world to the others and imagines and invents a friend and company to console her.

As a little girl having witnessed her mother's abandonment of her, Florens feels insecure and inferior to all the people. The scene that her mother chooses her little brother and gives up her lingers in her mind again and again. In her dreams, what she saw first is always that her mother has her little brother in arm. Though in the dreams her mother wants to tell her something, she looks away from her mother and refuses to hear her mother's explanation. On her way to the blacksmith, she rather says that her mother is dead for the grudge on her mother. When she sees the care and love the Widow Ealing gives to Jane, she could not help envying the girl's happiness, "You never tell me that and it is a good thing to know. If my mother is not dead she can be teaching me these things" (Morrison, 2008: 109). As she sees the people trying to take Jane away, she thinks it is sweet that the mother screams and pleads to keep her daughter which reminds her of her experience when her mother sends her away. In the mind of a seven or eight years old girl, she cannot understand why it is not her whom her mother chooses and why her mother abandons her. To get rid of her feeling of inferiority caused by the abandonment by her mother, she tries to get compensation from others' love and affection. She has adopted two means to compensate her feeling of inferiority, over-sentiment and 
fragile feet and the love without herself, both of which concentrated on her own being.

\section{A. Compensation by Fragile Feet}

According to Adler's theory, the aim of little children is to gain attention. As long as the children find that once they have some activity or habit that will attract other's attention, worry or anxiety, children with an increased, intensified, and longer lasting inferiority feeling will feel like they have found a way to draw other's attention, care and love. Only by the unusual behaviors can they get the attention and care they long for. For example, some children will wet the bed at night, but neither in the day. The behavior sometimes will disappear suddenly as there is no enough attention paid on it. If the habit no longer serves to the purpose of attraction attention, for example, the parents change their attitude on the urinating into neglect, they will give it up. In that case, the behavior servers to the sole purpose of getting attention for people with inferiority feelings as they have no other way attracting attention or care from others than getting others worried about them.

Florens keeps mild and sentiment to the others to protect her from hurting. Her feet are especially fragile to the tough life. Since she was very young she has wished not to be barefoot and has begged for shoes even on the hottest days. Even the thrown-away shoes with pointy-toe and broken heel would make her out of joy. As a slave, her feet are too tender for life and there are no strong soles that her life requires. Actually, the thirst for shoes is exactly the desire for love and attention. With the fragile and sensitive feet, she wants to draw others' attention and care to compensate her inferiority of 1 hunger for love. Only with the illusion that her feet are more delicate and fragile than others', can she find an aspect that she is not inferior to others. That she owns a pair fragile feet are just an excuse for her to remind others that she needs more attention and more love.

\section{B. Love of Devotion to the Blacksmith}

Florens' focus in life is just her self's getting love. As long as she falls in love with the blacksmith, the passionate love from the blacksmith becomes the spring of her life. She regards him as her protection, and her world. Seeing his back, she thinks of the image of sunlight and moonrise. "Before you know I am in the world I am already kill by you" (Morrison, 2008: 38). She is lost in the love so deeply that she even steals a candle and sneaks in to watch the blacksmith sleeping. She stares so long that the flame burns the palm. She fears of her peep being known by the blacksmith, however, next time when she meets him, she finds nothing happened and then realizes that "for the first time I am live." (Morrison, 2008: 38) It's her inferiority that makes her overcareful and fearful of everything. After failing to get attention and love from her fragile feet, she is even afraid to show her hurt to others. Every time she gets hurt she refuses to cry. Whenever the sad things emerge into her thoughts, she thinks of the blacksmith instead, just avoiding facing the pains. And the blacksmith becomes the sole consolation and protection for her. With the strong protection, she locks herself in the imaginary world of her happiness. Due to the deficiency of love and that is all she can cling to, she is desperate in the relationship with the blacksmith as she called that "No holy spirits are my need. No communion or prayer. You are my protection. Only you" (Morrison, 2008: 69). All her expectations for love have been pinned on the blacksmith. Her appeal is great and the concentration on her stresses so much that herself gets lost in the relationship. There is no "I" but "you"; "you" are my world; "you" are my protection; and "you" are my shaper and my world as well. "You" are the reason for "I" live. Her life wilts when the blacksmith leaves and goes back to be straight when she is sent to find him. Even she knows there is no possibility for him to take her away or wed her, she just insists on her love which seems to be her last straw that could save her from the feeling of inferiority. Her love, happiness and life are not in her control, but her mistress and the blacksmith. The love totally relies on the others results in failure because Florens is not an independent human being and lives in insecurity and turbulence.

As she finds there is a little boy at the blacksmith's, she finds the danger of being expelled again. She recalls the image that her mother chooses her little brother rather than her. She is even worried about the boy's stepping close to the blacksmith. She envies that the boy owns the blacksmith's forefingers and he seems to be the future of the blacksmith rather than her. Her world is fully filled by the blacksmith and her love to the blacksmith, and she cannot bear even a hint of the blacksmith's love being possessed by others. There is no space for others at all. Out of her defense against the little boy, she detects his hate in eyes and his wanting of her leaving. "He wants my leaving. This cannot happen I feel the clutch inside. This expel can never happen again" (Morrison, 2008: 137). As she feels the danger of expelling, she tells herself and soothes herself that the expelling she had would never happen again. However, that indeed happens again. When the blacksmith finds out she is scratching the little boy and his mouth is hit bleeding by the table corner, he shouts at her. At that moment, all the hope and faith on her love and her lover have collapsed. "I don't hear your horse only your shout and know I am lost because your shout is not my name. Not me. Him. Malaik you shout. Malaik" (Morrison, 2008: 140). Depressed and disappointed at that, she is shocked and heartbreaking. With her pale and powerless explanation of what she has done, she feels grieved and doubted.

Yes, there is blood. A little. But you are not there when it comes, so how do you know I am the reason? Why do you knock me away without certainty of what is true? You see the boy down and believe bad about me without question. You are correct but why no question of it? I am first to get the knocking away. The back of your hand strikes my face. I fall and curl up on the floor. Tight. No question. You choose the boy. You call his name first. You take him to lie down with the doll and return to me your broken face, eyes without glee, rope pumps in your neck. I am lost. No word of sorrow for knocking me off my feet. No tender fingers to touch where you hurt me. I cower. (Morrison, 2008: 140) 
Aggrieved as she was, the blacksmith still chooses to expel her and send her back to Rebekka. The reason he wants her to go and gives her no opportunity to explain is not only she is a slave physically, but also a spiritual slave with head empty and body wild. Without constraint and mind, the love is too crazy and wild to own a normal and healthy relationship of love. The reaching for him on her knees and the crawling to him are no better than owning herself in building her love. Failing in getting the attention on her feet and the love from the blacksmith, her compensations do not make her out of inferiority feelings, but put her into even deeper inferiority that she is nothing to the blacksmith and has no consequence in his world at all.

\section{TRANSCENDENCE OF THE INFERIORITY FEELINGS}

As Alfred Adler proposed, only by developing social interest can people get rid of the inferiority feelings. "Social interest is the true and inevitable compensation for all the natural weaknesses of individual human beings." (Ansbacher, 1956: 154) It states that as social beings, the human beings need the care and help from others until they are mature enough to be independent. The human being's life is dependent on his adjustment to the world. "Good adjustment is the striving on the commonly useful side, while poor adjustment is the striving on the commonly useless side" (Ansbacher, 1956: 154). The reason for an individual to side-step to the useless side is that the fear of a defeat on the useful side. Those with inferiority feelings are people who are lacking in social interest and cannot adjust the world successfully. "The meaning they give to life is a private meaning $\cdots . . \cdot$ Their goal of success is a goal of personal superiority, and their triumphs have meaning only to themselves" (Ansbacher, 1956: 156). Therefore, the key to transcend the inferiority feelings is to develop the social interest and to feel value by contributing to the common welfare.

As the feeling of worth and value heightened, people are given courage to do the useful things. In that case, they feel at home in life and feel the existence to be worthwhile just so far as they are useful to others, and then they overcome the feelings of inferiority. In A Mercy, the blacksmith is the symbol of people with social interest. He is independent, free and has his own will. He is neither humble nor overbearing to the others. He could be the ideal man in the novel and the savior to Jacob's farm. He has saved Sorrow's life, and he is envied and appreciated by Willard and Scully, fascinated by Florens and taken as brother by Jacob. He is nice to everyone that only he would answer Sorrow with smile. As Jacob died, he comes without any fear of infliction and cures Sorrow and Rebekka. He even goes to Jacob's grave and mourns him with hat taken down. He wants to protect the little boy left by his parents and asks Florens to take care of him when he goes to Jacob's farm. As he sees the little boy bleeding in the mouth, he gets mad at her and takes her as a wild woman without free personality. It is he who points out that the love without constraint and mind is nothing but wildness. As he is asked by Lina that when Florens will return and he cannot keep her against her will, he just answers that "when it suits her she will come" (Morrison, 2008: 130) without any hesitation. In his mind, Florens is an independent person who should own herself and dominate her own life. Accordingly to Adler, as a free and independent human being, the blacksmith "is ready to accept the advantages of our social life and is a good loser whenever disadvantages cross his way" (Ansbacher, 1956: 156). He has the courage and common sense to confront all the frustration and failures in life and he is "the master of his fate with an effective regard for the welfare of others" (Ansbacher, 1956: 156).

According to Adler's theory about the inferiority feelings, the transcendence of inferiority feelings is gotten by the development of the social interest. The inferiority feelings can be transcended only when people can get the feeling of being valuable to the others. Having never been adored and protected in childhood, Florens desperately wants to get love and care from others, especially her mother. Without getting any kind of interest or attention from the society, she gets no interests in the world either. Setting her goal and interest on herself only, she turns her interest on herself being. However, the more she focuses on herself, the more her inferiority feelings are accumulated. After all the frustrations and failures of her pursuit of love from others, she learns to grow mature and independent. The blame on everyone and everything except herself cannot help her out of her misery, and the continuous asking for love blindly cannot ease up her inferiority feelings. Being grown up and mature, Florens' transcendence is accomplished both by her feet and her passion for the Blacksmith.

\section{A. Transcendence of Being Spiritually Independent}

In order to draw other's attention and make compensation for her fragile and sensitive heart, she puts all her focus on her feet. Her feet are so fragile that could not bear any pain and hurt. However, she does not obtain other's attention by her fragile shoes. Moreover, she is offered to send out by her own mother and she could not endure the great pain of her own mother's abandonment. Having failed to get any protection or love, finally it dawns on her that what she needs is not a pair of fragile feet, but a tough one which are as hard as cypress. With the tough feet, she needs no extra care of her feet any more.

After the blow of the blacksmith, she grows up and becomes mature. She turns to be strong and feral in life. On her returning to Jacob's farm, she is "blood-spattered and bedraggled" (Morrison, 2008: 146) with the bare feet bloody, but with proud. As she walks through forests, she does not care what the signs meant any more. "Heads of dogs, garden snakes, all that is pointless." (Morrison, 2008: 157) All the fears and fragility have been out of her mind. "Color so loud it hurts the eye and for relief I must stare at the heavens high above the tree line" (Morrison, 2008: 158). The color is shining so loudly that it hurt the eye. However, to get a relief or a reborn, she decides to stare at it. It shows her strong determination to face the difficulty and get down handling it. 
As she comes to Jacob's farm, she tries her best to get appreciation and care from others and even is grateful for an approval smile and slight pat on her head. Immediately after she meets the blacksmith, she is obsessed with him. All her world exists just for him and he is no more than a lover to her, he is also her whole world and the meaning of her being. The blacksmith is the one whom she regards always as her life and her security from harm, from any who looks closely at her only to throw her away, and from all those who believe they have claim and rule over her. It seemed to her that he is the last hope for her to gain love and protection. The blacksmith's expel has destructed her faith in love and her belief that her life is dependent on the blacksmith.

Instead of getting relief from her inferiority feelings of love-hunger by resting hope on the blacksmith, she begins to do it by herself. By writing her story and feelings on the walls, she pours out all her misery and builds up her belief in life. Even no one sees her words, "these careful words, closed up and wide open, will talk to themselves" (Morrison, 2008: 161). And she does not need the sympathy or protection from others any more. She claims that she becomes wilderness indeed, but she is also Florens herself. She is a slave, but free in her mind and soul as she shouts on the wall, "Hear me? Slave. Free. I last" (Morrison, 2008: 161). After the shattering of her love fantasy, even barefoot with no protection of the shoes, she strides forward bravely. The fragile feet have become tough and hard as cypress and need no attention and protection from anyone any more.

\section{B. Transcendence by Confronting her Mother's Abandonment}

As offered to Jacob by her mother, Florens lives in the nightmare of being abandoned. The scene has lingered on and on in her dreams, "saying something important to me, but holding the little boy's hand" (Morrison, 2008: 8). To Florens, the dream that cherry trees are walking toward Florens is even better than her mother "standing near with her little boy. In those dreams she is always wanting to tell me something. Is stretching her eyes. Is working her mouth. I look away from her" (Morrison, 2008: 101). Every time she recalls her mother, she keeps mentioning that her mother is with her little boy. It is not Florens' little brother, but her mother's little boy. Florens and her little brother are not as intimate as the bloody brotherhood should be, but on the contrary each of them is whom the other one competes with to get their mother's love. Florens fails in getting the upper side, so she chooses to escape the memory about her mother and little brother. The more she tries to avoid the memory, the more frequently she confronts.

Florens have grown mature after the devoted love to the blacksmith and learned to be independent and face her life bravely. Her feet were not as fragile as before and the soles were tough as the cypress. As having poured out all her tears and sadness, she realized that her life should not rely on others. The thirst for attention, care and love from others could not make useful compensation to the inferiority feelings. Only when she herself stands up, other than waiting for others' charity of care or love, could she really transcend her inferiority feelings and make a life in the tough world. As grown mature, Florens chooses to confront the tough world bravely. Though she did not know what she would do with the nights when the telling stoped, she claimed that "dreaming will not come again" (Morrison, 2008: 160) She doesn't fear of dreaming the scene of her mother and the little boy any more. It won't be her nightmare any more. Though she doesn't know why her mother abandons her, she doesn't care. From then on, she becomes one trying to seize her life and happiness by her own hands.

\section{CONCLUSION}

Toni Morrison regards her writing as the description of the African American's experiences from the perspective of a woman to reveal the evil built on the racial discrimination. To rebut the white's prejudice and ignorance on the black, she tries to build a world with the theme of anti-racism. The black people have suffered a lot in the long term of the slavery system. In the new novel A Mercy, Toni Morrison tries to find the root of the blacks' suffering which does not lie in the blackness in their color, but the slavery system. To show there is no inevitable connection between the black people and the slavery system, she sets the novel in the beginning period of North American colony when there are also the Indian natives and the indentured white servants living as slaves.

Living in slavery system, people are not only tortured physically, but also spiritually. The memories in childhood reveal people's inner world and influence their whole life. Lack of warmth and love in childhood, all the characters in A Mercy, including the White, the landowner and slaves, feel no security at all. In the shadow of being abandoned by family and the contempt from the society, people cannot get rid of the inferiority feelings as the inferiority feelings are deep-rooted in the mind of those people. It is love that they lack, and that they cannot give to others. Suffering in the slavery deprives of people's right to get love from the closest ones and people in the society, and also deprives of people's ability to love. Those people are loved by no one and no one needs their love, so they find no value of their lives in the world. As value is the whole meaning of life, life without value means life with no meaning at all. In this case, the inferiority feelings are accumulated.

With the drive toward above according to Adler's theory, people will try hard to shake off the yoke of the inferiority and prove their values of life. They have no other choice but resort to the transformation of the drive to others to get themselves satisfied and get the superiority feelings. Florens and Sorrow have directed all their energies and focuses on themselves and they lock themselves in their own world to protect themselves from hurt. Lina, Willard, Scully and Jacob have displaced their efforts of getting rid of inferiority feelings to another goal. Lina displaces her thirst for love to Florens. Willard and Scully have nothing to stand in the world and have to support each other regardless of others' eyes and Jacob thinks the only way he stands in the world is to build a grand house, so he devotes himself to building a grand house. Rebekka finds she has been abandoned by the world, even by her dearest husband, she 
changes her personality totally which can be called as the transformation of the drive into its opposite. However, these transformations cannot improve the tough situation, because they aim at escaping from the difficulties other than overcoming them. The improper compensation just leads to the more serious inferiority and people cannot walk out of the shadow. Only by rebuilding the independent characteristics and developing the social interests can they gain a new self and transcend the inferiority feelings.

The disastrous effects the slavery system leaves have rooted deeply in people's blood. Being slaves in heart, they cannot shatter their inferiority feelings by one certain compensation. The inferiority feelings can be transcended only when they have developed the independent souls. With the independent souls, they are confident to do things useful and valuable to others and the society. Once they find they are useful and valuable, the inferiority feelings are transcended. Florens has shatters her fantasies that she could attract others' attention and love by her fragile feet and she could depend on the blacksmith totally without her own self. Finally her feet are as tough as cypress and she is not afraid of dreaming her mother any more. Moreover, she gets spiritually independent as she doesn't care whether the blacksmith sees her inner thought inscribed in the wall or not. The other little girl, Sorrow, comes back to the reality due to the identity of a mother. As a mother, she realizes her responsibility for taking care of her baby and she finds her value in her baby. Being valuable and useful for others, she gets her inferiority feelings transcended. In a word, what they need is the self-accomplishment. Without the value people get in the society, they can never transcend the inferiority feelings actually. The independent and free souls are the true recipe they need to be real men, not slaves.

\section{REFERENCES}

[1] Adler, Alfred. The Practice and Theory of Individual Psychology [M], translated by P. Radin, Kegan Paul, Trench, Trubner\& Co. Ltd., London, 1924

[2] Ansbacher, Heinz L and Ansbacher, Rowena R. ed. and annotated, The Individual Psychology of Alfred Adler: A Systematic Presentation in Selections from His Writings[M], Basic Books,New York, 1956

[3] Carlson, Jon., Watts, Richard E. and Michael Maniacci, Adlerian Therapy: Theory and Practice [M], American Psychological Association, Washington, DC., c2006.

[4] Eagleton, Terry. Literary Theory: an Introduction [M]. 2nd edition. Beijing: Foreign Language Teaching and Research Press, 2004.

[5] Furman, Linden. Toni Morrison's Fiction [M]. Columbia: University of South Carolina Press, 1996.

[6] Gates, David. "Original Sins" [N], The New York Times, http://www.nytimes.com/2008/11/30/books/review/Gatest.html?scp=4\&sq=\&st=nyt, November 28, 2008.

[7] Higgins, Therese E. Religiosity, Cosmology, and Folklore: the African Influence in the Novels of Toni Morrison [M]. New York: Routledge, 2001.

[8] Hoffman, Edward. The Drive for Self: Alfred Adler and the Founding of Individual Psychology [M], Reading, Mass.: Addison-Wesley Pub. Co., 1994.

[9] Kakutani, Michiko. "Bonds That Seem Cruel Can Be Kind" [N], The New

York

Times, http://www.nytimes.com/2008/11/04/books/04kaku.html?scp=5\&sq= \&st=nyt, November 3, 2008.

[10] Mbalia, Doreatha Drummond. Toni Morrison's Developing Class Consciousness [M]. Selinsgrove: Susquehanna University Press, London and Toronto: Associated University Press, 1991.

[11] McKay, Nellie Y. "An Interview with Toni Morrison" [J], Contemporary Literature. (4), 1983.

[12] McKeown, Jennifer, "Mothers and Daughters" [EB/OL], http://www.pajiba.com/book_reviews/a-mercy-book-review.php, December 17,2008.

[13] Morrison, Toni. A Mercy [M]. Canada: Alfred A. Knopf Canada, 2008.

[14] Morrison, Toni. Beloved [M]. Canada: Alfred A. Knopf Canada, 1987.

[15] Morrison, Toni. Love [M]. Canada: Alfred A. Knopf Canada, 2003.

[16] Norris, Michelle, "Toni Morrison Finds A Mercy in Servitude" $[\mathrm{EB} / \mathrm{OL}]$,

http://www.npr.org/templates/story/story.php?storyId=96118766, October 27, 2008

[17] Peach, Linden. ed. Toni Morrison [M]. New York: St. Martin's Press, 1998.

[18] Taylor-Guthrie, Danille., ed. Conversations with Toni Morrison [M] Jackson: University Press of Mississippi Jackson, 1994.

[19] Zhu Rongjie. Pain and Healing: A Study of Maternal Love in Toni Morrison's Fiction from a Cultural Perspective [M]. Henan: Henan University Press, 2004 